

\title{
PERBANDINGAN LATIHAN PUSH UP DAN BEBAN DUMBELL TERHADAP KECEPATAN PUKULAN STRAIGHT PADA ATLIT TINJU AMATIR SASANA LIPANG BAJENG KABUPATEN TAKALAR.
}

\author{
Melerand Evert Latuheru' Welem Arawaman lolangluan ${ }^{2}$ Hermanus Wattimury $^{3}$ \\ Prodi Penjaskesrek, FKIP Universitas Parttimura Ambon \\ Latuherum@gmail.com¹.welemalolangluan@gmail.com² Hermanuswattimury@gmail.com³
}

\begin{abstract}
ABSTRAK
Penelitian bertujuan untuk mengetahui tentang perbandingan latihan push up dan beban dumbell terhadap kecepatan pukulan straight pada atlit tinju amatir. Jenis penelitian kuantitatif bentuk eksperimen dengan menggunakan pendekatan cross sectional study. Populasi adalah seluruh atlit tinju amatir sasana lipang bajeng sebanyak 30 sampel. Teknik pengambilan sampel dengan cara sampling jenuh. Populasi digunakan sebagai sampel Instrument Penelitian yang dibagi dalam 2 kelompok berjumalah 15 orang. Teknik tenik pembagian kelompok menggunakan metode Randomized group, Sedangkan menggunakan uji T-test. Hasil penelitian menunjukan bahwa tidak ada perbandingan serta perbedaan signifikan antara latihan push up dengan beban dumbell terhadap kecepatan pukulan straight 0,454 , dilihat nilai thitung push up dan beban dumbell $-0,770$.
\end{abstract}

\section{COMPARISON OF PUSH UP AND DUMBELL LOAD TRAINING ON STRAIGHT BEATING SPEED ON AMATIR TATUO ATATIT ATLIT SASAN LIPANG BAJENG TAKALAR DISTRICT}

\section{ABSTRACT}

This study aims to find out about the comparison of push up training and dumbbell weights to the speed of a straight punch in amateur boxing athletes. This type of quantitative research is an experimental form using a cross sectional study approach. The population is all 30 boxing amateur boxing athletes. The sampling technique is by sampling saturation. The population was used as a sample of Research Instruments divided into 2 groups of 15 people. The technique of group division technique uses the Randomized group method, while using the T-test. The results showed that there was no comparison as well as a significant difference between push-up training with dumbbell load to 0.454 straight stroke speed, seen from the t-count of push-up and dumbbell load 0,770

\section{PEMBAHASAN}

Berdasarkan Bermasalahan tersebut, maka salah satu upaya yang dilakukan untuk meningkatkan kecepatan pukulan adalah dengan melatih kondisi fisik atau latihan fisik. Bompa (1994) mendefinisikan bahwa:

Latihan atau melath kondisi fisik atlet adalah suatu upaya yang sistematis dan ditujukan kepada peningkatan kemampuan fungsional atlet sesuai dengan tuntutan cabang olahraga yang ditekuni sehingga dapat mencapai standar yang telah ditentukan.

Dengan demikian kemampuan fisik merupakan salah satu faktor yang sangat esensial dalam menunjang peningkatan kecepatan pukulan. Hal ini disebabkan karena tanpa kemampuan fisik yang 
memadai maka sulit untuk mengembangkan teknik pukulan yang benar, begitu pula sebaliknya dengan kemampuan fisik yang prima maka pelaksanaan teknik pukulan akan dapat ditampilkan secara sempurna.

Kemampuan fisik tersebut terutama ditekankan pada bagian tubuh yang memegang peranan penting dalam melakukan pukulan, seperti unsur fisik kecepatan lengan. Oleh karena itu untuk dapat meningkatkan kecepatan pukulan maka dapat dilakukan dengan memberikan latihan-latihan fisik yang teratur dan sistematis melalui penerapan metode atau bentuk-bentuk latihan yang berfokus pada kecepatan pukulan serta harus berpedoman pada prinsip-prinsip latihan.

Push up juga merupakan suatu jenis senam kekuatan yang berfungsi untuk menguatkan otot bisep maupun trisep. Posisi awal tidur tengkurap dengan tangan di sisi kanan kiri badan kemudian badan di dorong ke atas dengan kekuatan tangan posisi kaki dan badan tetap lurus atau tegap setelah itu badan di turunkan dengan tetap menjaga kondisi badan dan kaki tetap lurus. Badan turun tanpa menyentuh lantai atau tanah, naik lagi dan di lakukan secara berulang- ulang. Program latihan push up sangat baik diterapkan bagi atlit tinju, karena dapat mebantu atlit agar meningkatkan teknik dasar berupa teknik pukulan yang baik dan tepat khususnya bagi atlit tinju amatir Sasana Lipang Bajenng Kabupaten Takalar.

Begitu pula halnya dengan latihan dumbell juga merupakan salah satu bentuk latihan fisik beban, dimana dumbell dijadikan sebagai alat beban dalam pelaksanaan latihan tersebut. Bentuk latihan ini bila dilakukan secara teratur, sistematis dan berkesinambungan melalui program latihan yang tepat serta berpedoman pada prinsip-prinsip latihan, maka akan dapat meningkatkan unsur fisik kekuatan dan kecepatan lengan, dimana unsur fisik ini sangat berperan dan mendukung terciptanya pukulan yang cepat. Dengan demikian di duga bahwa penerapan latihan dumbell dalam penelitian ini mempunyai pengaruh terhadap peningkatan kecepatan pukulan dalam tinju.

Berdasarkan pengamatan selama ini, prestasi atlit tinju Sasana Lipang Bajeng Kabupaten Takalar tergolong cukup bagus, oleh karena itu peneliti melakukan pengamatan dilapangan, berupa program pelatihan untuk meningkatkan kecepatan pukulan salah satunya yakni meningkastkan kecepatan pukulan straight, yang sangat perlu mendapatkan perhatian yang serius. Oleh karena itu, maka perlu dilakukan penelitian tentang pelatihan yang bertujuan untuk meningkatkan kecepatan pukulan straight. Menurut pendapat Ron Gabe P. Simbolon:

Kecepatan merupakan salah satu unsur dalam fisik. Kecepatan adalah kemampuan dari reaksi otot yang ditandai dengan perubahan antara kontraksi dan relaksasi untuk menuju frekuensi maximal". Memukul dalam tinju harus memiliki kecepatan yang bagus dan tepat, karena dengan pukulan yang semakin cepat merupakan faktor yang sangat menentukan untuk mendapatkan pointnilai. Termasuk pukulan straight, kecepatan pukulan ini akan dibantu dengan eksplosif (meledak dalam suatu gerakan) otot lengan. Untuk memperoleh kecepatan dibutuhkan suatu latihan yang tepat. Maka dari itu pelatih harus cermat dan tepat dalam menerapkan program latihan.

Struktur tubuh merupakan aspek fisik yang menetukan dalam pembinaan kemampuan olahraga. Hampir semua cabang olahraga yang menjadi faktor untuk menentukan prestasi terletak dari postur tubuhnya diantara faktor-faktor lainnya, akan tetapi faktor tubuh seseorang biasanya dihubungkan dengan kemampuan fisiknya sebagaimana dikemukakan oleh Mohammad sanjoto (1998) menguraikan bahwa :

"struktur tubuh yang tinggi lebih baik gerakannya bila dibandingkan dengan struktur tubuh yang pendek, hal ini dipengaruhi aktivitas gerakan tubuh dalam melakukan gerakan olahraga".

Begitu pula dengan kemampuan fisik seseorang dalam melakukan suatu kegiatan, petinju khususnya kondisi fisik akan mempengaruhi kemampuan gerak yang akan menentukan pencapaian prestasi. Nur Ichsani Halim (2004) mengemukakan bahawa :

"Kondisi fisik merupakan satu prasyarat yang sangat diperlukan dalam usaha peningkatan prestasi seorang atlet, bahkan dapat dikatakan sebagai keperluan dasar yang tidak dapat ditunda atau ditawar-tawar lagi. Kesepuluh komponen tersebut sebagai berikut : 
kekuatan, daya tahan, daya ledak, kecepatan, daya lentur, kelincahan, koordinasi, keseimbangan, ketepatan, dan reaksi.

Inilah yang mendorong peneliti mengadakan suatu penelitian dengan judul "Perbandingan Latihan Push Up Dan Latihan Beban Dumbell Terhadap Kecepatan Pukulan Straight Pada Atlit Tinju Amatir Sasana Lipang Bajeng Kabupaten Takalar Provinsi Sulawesi Selatan".

\section{METODE}

Kerangka berfikir merupakan penjelasan sementara terhadap gejala yang menjadi objek permasalahan dan merupakan pengantar argumentasi diajukan. Berdasarkan tinjauan pustaka, maka kerangka berpikir yang merupakan dasar dalam merumuskan hipotesis dapat diuraikan sebagai berikut:

1. Jika pada atlet tinju amatir diberikan latihan push up secara teratur dan sistematis melalui pogram latihan pushup maka dapat meningkatkan kecepatan pukulan straight pada atlet tinju amatir Sasana Lipang Bajeng, Kabupaten takalar.

2. Jika pada atlet tinju amatir diberikan latihan dumbell secara teratur dan sistematis melalui program latihan dumbell maka dapat meningkatkan kecepatan pukulan straight pada atlet tinju amatir Sasana Lipang Bajeng, Kabupaten Takalar.

3. Jika atlet tinju amatir diberikan bentuk latihan yang berbeda, yakni melakukan latihan push up dan melakukan latihan dumbell, maka akan menghasilkan perbedaan terhadap peningkatan kecepatan pukulan straight pada atlet tinju amatir Sasana Lipang Bajeng, Kabupaten Takalar.

\section{POLA PIKIR VARIABEL YANG DI TELITI}

Berdasarkan konsep pemikiran variabel seperti yang dikemukakan di atas, maka disusunlah pola pikir variabel yang diteliti sebagai berikut :

\section{Pola PikirVariabel Yang Di}

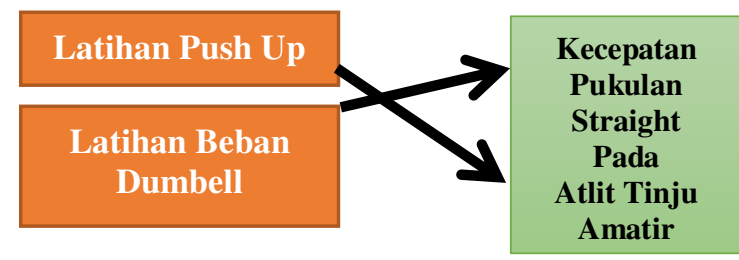

Gambar 1. Skema kerangka konsep penelitian (Diadaptasi dari teori Alport dalam Mar'at., 1991) upraptojielwongsolo (Oktober 29, 2010balian86) :

Secara umum, jenis variabel (dilihat dari sifat hubungan antar variabel) dapat dibedakan pada variabel indenpenden dan variabel dependen. Istilah variabel independen dan variabel dependen berasal dari logika matematika, di mana $X$ dinyatakan sebagai yang 'mempengaruhi atau sebab' dan $Y$ sebagai yang 'dipengaruhi atau akibat'. Namun pengertian ini tentu tidak selalu menggambarkan hakikat yang sebenarnya dari konsep variabel independen dan dependen. Sebab dalam kenyataan, khususnya dalam penelitian ilmu-ilmu sosial, hubungan antar variabel tidak selalu merupakan hubungan kausal. Yang dapat dipastikan adalah, bahwa terdapat variabel yang saling berhubungan, di satu pihak ada yang disebut variabel independen dan di pihak lain ada yang disebut variabel dependen. Kedua variabel ini diperlukan oleh setiap penelitian kuantitatif. Adapun sifat hubungan itu ada yang bersifat kausal, dan ada yang tidak.

\section{HIPOTESIS}

Sesuai dengan erangka berpikir yang telah dikemukakan di atas, maka hipotesis yang diajukan dalam penelitian ini adalah sebagai berikut: 
1. Ada pengaruh latihan push up terhadap kecepatan pukulan straight pada atlet tinju amatir Sasana Lipang Bajeng, Kabupaten Takalar.

2. Ada pengaruh latihan dumbell terhadap kecepatan pukulan straight pada atlet tinju amatir Sasana Lipang Bajeng, Kabupaten Takalar.

3. Ada perbedaan pengaruh antara latihan push up dengan latihan dumbell terhadap kecepatan pukulan straight pada atlet tinju amatir Sasana Lipang Bajeng, Kabupaten Takalar.

Hipotesis statistik yang diuji:
a. $\mathrm{H}_{0}: \square \mathrm{A} 1=\square \mathrm{A} 2$
$\mathrm{H} 1: \square \mathrm{A} 1 \square \square A 2$
b. $\mathrm{H}_{0}: \square \mathrm{B} 1=\square \mathrm{B} 2$
$\mathrm{H} 1: \square \mathrm{B} 1 \square \square \mathrm{B} 2$
c. $\mathrm{H}_{0}: \square \mathrm{A} 2=\square \mathrm{B} 2$
$\mathrm{H} 1: \square \mathrm{A} 2 \square \square \mathrm{B} 2$

Kiteria Pengujiaan

1) Jika nilai probilitas $(P)>0.05$, maka tolak $\mathrm{H}_{1}$ dan terima $\mathrm{H}_{0}$

2) Jika nilai probilitas $(\mathrm{P})<0.05$, maka tolak $\mathrm{H}_{0}$ dan terima $\mathrm{H}_{1}$

\section{IDENTIFIKASI VARIABEL DAN DESAIN PENELITIAN}

\section{Variabel penelitian}

Dalam penelitian ini, ada dua variabel yang terlibat yakni variabel bebas dan variabel terikat. Kedua variabel tersebut akan diidentifikasikan ke dalam penelitian ini sebagai berikut:

a. Variabel bebas yakni :

1) Latihan push up

2) Latihan dumbell

b. Variabel terikat yakni :

Kecepatan pukulan straight 59

\section{Desain penelitian}

Jenis penelitian ini adalah penelitian yang bersifat eksperimen atau perlakuan yang bertujuan untuk mengetahui ada tidaknya perbandingan latihan Pushup dan latihan beban dumbell terhadap kecepatan pukulan straight pada atlet tinju di Sasana Lipang Bajeng. Oleh sebab itu, rancangan analisis dari eksperimen ini adalah "Randomized Group Pretest-Postest Design".

Secara sederhana model desain penelitian ini dapat dilihat pada gambar berikut ini:

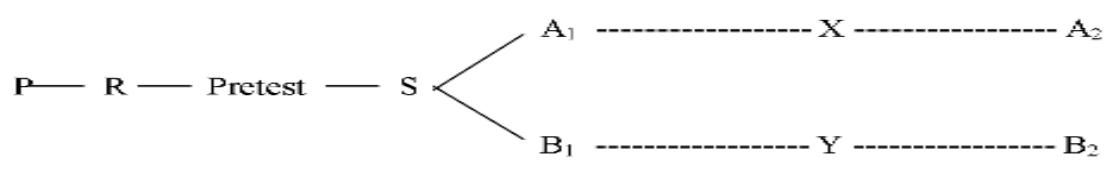

Gambar 10. Model desain penelitian. Sumber : Nana Sudjana (1986)

Keterangan:

$\mathrm{P} \quad=$ Populasi

$\mathrm{R} \quad=$ Random sampel

Pretest = Tes awal kecepatan pukulan straight

$\mathrm{S} \quad=$ Pembagian kelompok sampel berdasarkan hasil tes awal

$\mathrm{A}_{1}=$ Hasil tes awal kelompok A B1 $=$ Hasil tes awal

kelompok $\mathrm{B} X \quad=$ Penerapan latihan push up $\mathrm{Y}=$ Penerapan latihan dumbell

A2 = Hasil tes akhir kelompok A B2 = Hasil tes akhir kelompok $B$ 


\section{DEFINISI OPERASIONAL VARIABEL}

Untuk menghindari terjadinya salah pengertian terhadap variabel yang terlibat dalam penelitian ini, maka variabel-variabel tersebut perlu didefinisikan secara operasional sebagai berikut:

1. Latihan push up yang dimaksud adalah merupakan salah satu bentuk latihan fisik yang juga bertujuan untuk menguatkan otot bisep dan trisep. Pelaksanaan latihan ini dilakukan dalam posisi awal tidur tengkurap dengan tangan di sisi kanan kiri badan setela $\mathrm{h}$ itu, badan diturunkan dengan tetap menjaga kondisi badan dan kaki tetap lurus. Badan turun tanpa menyentuh lantai atau tanah. Naik lagi dan dilakukan secara berulang sampai batas waktu yang ditentukan.

2. Latihan dumbell yang dimaksud adalah merupakan salah satu bentuk latihan fisik beban yang juga bertujuan untuk mengembangkan kinerja otot-otot lengan. Pelaksanaan latihan ini dilakukan dalam posisi berdiri dan kedua tangan memegang masing-masing dumbell. Gerakan ini dilakukan dengan mendorong dumbell kedepan seperti melakukan gerakan pukulan dalam tinju. Gerakan ini dilakukan secara berulang-ulang sampai batasan waktu yang ditentukan.

3. Kecepatan pukulan straight yang dimaksud adalah salah satu bentuk pukulan yang digunakan dengan jarak sepanjang lengan di segala arah, baik oleh tangan kanan maupun tangan kiri. Bila ingin melontarkan pukulan straight kanan, pindakan berat badan ke kaki kiri/tungkai kiri, pinggang dan putarlah bahu ke depan dengan berporoskan garis tengah badan dan luruskan lengan kanan kearah sasaran sejauh jangkauan lengan. Dalam penelitihan ini kecepatan pukulan straight di nilai dengan mencatat kecepatan pukulan yang dilontarkan sesuai dengan waktu yang telah di tentukan.

\section{POPULASI DAN SAMPEL}

1. Populasi

Populasi adalah keseluruhan individu atau kelompok yang dapat diamati dari beberapa anggota kelompok (Suharsimi Arikunto, 1996). Adapun yang dijadikan populasi penelitian ini adalah seluruh atlit tinju amatir Sasana Lipang Bajeng yang berjumlah 30 orang.

2. Sampel

Sampel ialah sebagian dari anggota populasi yang diambil dengan menggunakan teknik tertentu yang disebut teknik sampling (Usman. H dan Akbar. S, 1998:44). Oleh sebab itu, sampel dalam penelitian ini adalah sebagian dari individu yang mewakili atlit tinju amatit Sasana Lipang Bajeng Kab.Takalar.

Mengingat populasi dalam penelitian ini yakni atlit tinju amatir Sasana Lipang Bajeng jumlahnya relatif sedikit sehingga tidak dilakukan pemilihan sampel, dengan kata lain bahwa pengambilan sampel dilakukan pada semua populasi yang ada atau disebut juga sampel total. Adapun jumlah sampel dalam penelitian ini adalah sebanyak 30 orang atlit tinju amatir yang berumur 15 sampa 20 tahun.

Setelah sampel tersebut diperoleh, kemudian dilakukan tes awal kecepatan pukulan yaitu kecepatan pukulan straight yang kemudian disusun menurut rangking. Dari hasil rangking tersebut kemudian dibagi kedalam dua kelompok yang seimbang yakni masing-masing terdiri dari 15 atlet pada setiap kelompok. Teknik pembagian kelompok yang digunakan adalah teknik machid ordinal.

Cara pembagiannya dapat dilihat pada gambar dibawah ini :. 


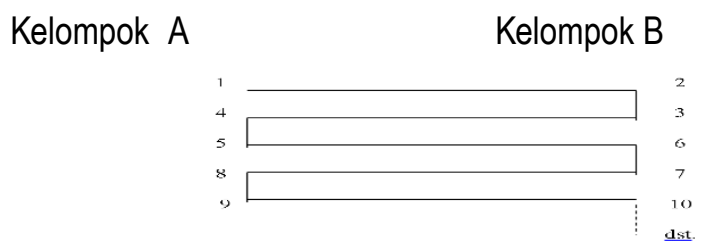

Gambar 11. Teknik pembagian kelompok.

Demikianlah pembagian kelompok tersebut dan seterusnya sampai masing-masing kelompok berjumlah 15 orang atlet.

\section{TEKNIK PENGUMPULAN DATA}

Teknik pengumpulan data merupakan syarat mutlak yang harus dipenuhi dalam melakukan suatu kerja ilmiah. Teknik pengumpulan data dalam penelitian

\section{Uji Hipotesis}

Hipotesis diajukan dalam penelitian ini akan diuji atau dibuktikan kebenarannya melalui data empiris yang diperoleh di lapangan melalui hasil program latihan pada atlit tinju amatir Sasan Lipang Bajeng Kabupaten Takalar, selanjutnya data yang didapat kemudian dianalisis secara statistik.

1. Hipotesis pertama : tidak ada perbedaan yang signifikan pada latihan push up terhadap kecepatan pukulan straight pada atlit tinju amatir Sasana Lipang Bajeng, Kabupaten Takalar.

Hipotesis yang akan diuji yakni :

$\mathrm{H}_{0}: \square \mathrm{A} 1=\square \mathrm{A} 2$

$\mathrm{H}_{1}: \square \mathrm{A} 1 \square \mathrm{AA} 2$

Sehingga dalam bentuk kalimat dapat diartikan bahwa :

$\mathrm{H}_{0} \quad$ : Tidak ada perbedaan yang signifikan pada latihan push up terhadap kecepatan pukulan straight pada atlit tinju Sasana Lipang Bajeng, Kabupaten Takalar.

$\mathrm{H}_{1} \quad$ : ada perbedaan yang signifikan pada latihan push up terhadap kecepatan pukulan straight pada atlit tinju Sasana Lipang Bajeng, Kabupaten Takalar.

Kriteria pengambilan keputusan yakni:

a. Jika nilai probabilitas lebih kecil atau sama dengan $a=0,05(P<0,05)$

maka $\mathrm{H}_{0}$ ditolak dan $\mathrm{H}_{1}$ diterima artinya ada perbedaan yang signifikan.

b. Jika nilai probabilitas lebih besar atau sama dengan $a=0,05(P>0,05)$ maka $\mathrm{H}_{0}$

diterima dan $\mathrm{H}_{1}$ ditolak artinya tidak ada perbedaan yang signifikan.

Dengan demikian dapat dikatakan bahwa nilai thitung sebesar $-0,770$ dan nilai sig. 0,454 (

$\mathrm{P}>0,05)$. Maka $\mathrm{H}_{0}$ diterima dan $\mathrm{H}_{1}$ ditolak artinya ada perbedaan yang signifikan. Pada latihan pushup terhadap kecepatan pukulan straight pada atlit tinju amatir pada Sasana Lipang Bajeng Kabupaten Takalar.

2. Hipotesis kedua : tidak ada perbedaan signifikan pada latihan beban dumbell terhadap kecepatan pukulan straight pada atlit tinju amatir Sasana Lipang Bajeng, Kabupaten Takalar.

Hipotesis yang akan diuji yakni:

$\mathrm{H}_{0}: \llbracket \mathrm{B} 1=\square \mathrm{B} 2$

$\mathrm{H} 1: \mathrm{B} 1 \square \square \mathrm{B} 2$

3. Hipotesis ketiga : tidak ada perbedaan pengaruh signifikan antara latihan push up dengan latihan beban dumbell terhadap kecepatan pukulan straight pada atlet tinju amatir Sasana Lipang Bajeng, Kabupaten Takalar.

$\mathrm{H} 0: \square \mathrm{A} 2=\square \mathrm{B} 2$

Sehingga dalam bentuk kalimat dapat diartikan bahwa : 
a. Apabila $\mathrm{H} 0$ diterima dan $\mathrm{H} 1$ ditolak berarti tidak ada perbedaan yang signifikan pada latihan push up dan beban dumbel terhadap kecepatan pukulan straight pada atlit tinju sasana lipang bajeng kab takalar.

b. Apabila $\mathrm{H} 0$ ditolak dan $\mathrm{H} 1$ diterima berarti tidak ada perbedaan yang signifikan pada latihan push up dan beban dumbel terhadap kecepatan pukulan straight pada atlit tinju sasana lipang bajeng kab takalar.

Kriteria pengambilan keputusan yakni :

a. Jika nilai probabilitas lebih kecil atau sama dengan $a=0,05 \quad(P<0,05)$

maka $\mathrm{H}_{0}$ ditolak dan $\mathrm{H}_{1}$ diterima artinya ada perbedaan yang signifikan.

b. Jika nilai probabilitas lebih besar atau sama dengan $a=0,05(P>0,05)$ maka $\mathrm{H}_{0}$ diterima dan $\mathrm{H} 1$ ditolak artinya tidak ada perbedaan yang signifikan

Dengan demikian dapat dikatakan bahwa nilai thitung $=0,454(\mathrm{P}<0,05)$ maka $\mathrm{H}_{0}$ ditolak dan $\mathrm{H}_{1}$ diterima artinya ada perbedaan yang signifikan pada push up dan latihan beban dumbel terhadap kecepatan pukulan straight pasa atlit tinju amatir sasama lipang bajeng kab takalar.

\section{PEMBAHASAN}

Untuk mengambil kesimpulan dalam suatu penelitian yang sesuai dengan tujuan penelitian, maka hasil dari analisis data perlu dibahaskan sesuai dengan teori yang mendasarinya. Hasil pengujian hipotesis pertama dalam penelitian ini menunjukkan bahwa terdapat perbedaan signifikan pada push up dan latihan beban dumbell terhadap kecepatan pukulan straight pada atlit tinju amatir sasana lipang bajeng kabupaten takalar.

Dalam penelitian ini berdasarkan hasil program latihan serta analisis data yakni menggunakan uji deskriptif, normalitas, homogenitas, dan uji T-test, maka didapatkan tidak ada perbedaan signifikan antara hasil latihan push up dan latihan beban dumbell terhadap kecepatan pukulan straight pada atlit tinju amatir sasana lipang bajeng kabupaten takalar. Hal ini sesuai dengan pengamatan di lapangan. Adapun dibahas sebagai berikut :

\section{LATIHAN PUSH UP}

Push up adalah suatu jenis senam kekuatan yang berfungsi untuk menguatkan otot bisep maupun trisep. Posisi awal tidur tengkurap dengan tangan di sisi kanan kiri badan kemudian di dorong ke atas dengan kekuatan tangan posisi kaki dan badan tetap lurus atau tegap setelah itu badan di turunkan dengan tetap menjaga kondisi badan dan kaki tetap lurus.

Latihan pada prinsipnya adalah memberikan tekanan fisik pada tubuh secara teratur dan sistematik, berkesinambungan sehingga akan menambah kemampuan atlet yang akhirnya akan meningkatkan kemampuan atlit. Dan untuk melaksanakan suatu latihan diperlukan metode latihan yang dapat diartikan sebagai suatu cara untuk mencapai tujuan.

Menurut Bompa (1994) "latihan adalah suatu aktifitas olahraga yang dilakukan secara sistematis dalam waktu yang lama ditingkatkan secara progresif dan individual mengarah kepada ciri-ciri fungsi fisiologis dan psikologis untuk mencapai sasaran yang telah ditentukan". Push-up with clap juga merupakan salah satu latihan untuk meningkatkan power otot- otot lengan Chu (1996) mengemukakan cara pelaksanaan latihan push-up with clap adalah : "latihan ini dilakukan dengan posisi psh-up (telungkup), lengan dipanjangkan, tangan bertepuk pada waktu berada di atas, dan kembali pada posisi awal" .

Latihan push-up, diharapkan berpengaruh terhadap power otot lengan karena bentuk latihan ini dapat meningkatkan kecepatan pukulan straight yang sangat dibutuhkan oleh atlit tinju amatir dalam menerapkan atau mengeluarkan teknik pukulan yang diharapkan untuk mendapatkan point atau hasil yang maksimal dalam sebuah pertandingan. 


\section{LATIHAN BEBAN DUMBEL}

Latihan beban dumbell yang dimaksud dalam penelitian ini adalah merupakan suatu bentuk latihan fisik beban dengan menggunakan beban dari luar berupa dumbell yang dijadikan sebagai beban dalam latihan. Bentuk latihan ini juga bertujuan untuk melatih kekuatan dan kecepatan otot lengan yang merupakan otot yang berperan penting dalam melakukan pukulan yang cepat pada olahraga tinju.

Menurut Dwi Anggoro (2011) mengatakan bahwa latihan beban adalah banyaknya variasi gerakan hanya dengan beberapa peralatan saja, seperti dumbell atau barbel. Kenyataannya, variasi dan kenyamanan dalam berolahraga merupakan kunci utama menjadi fit. Satu hal yang perlu diketahui, tidak ada satu jenis latihan atau olahraga yang mencukupi seluruh aspek

kebutuhan menjadi fit secara seimbang, termasuk dalam jenis-jenis latihan beban. Sebaiknya kita memiliki lebih dari satu jenis latihan agar tidak monoton. Penelitian juga menunjukan bahwa orang-orang cenderung memilih jenis aktifitas yang muda dan menyenangkan bagi mereka.

Dumbell merupakan salah satu latihan beban yang menggunakan berat dumbell. Latihan ini bertujuan untuk melatih otot- otot lengan. Otot yang terlatih dengan latihan dumbell press :

- Deltoid, middle, dan anterior

- Trisep

- Petrocalis mayor

- Upper trapezius

Sajoto (1988) mengemukakan cara pelaksanaan latihan dumbell press adalah :"latihan ini dapat dilakukan dengan posisi berdiri atau duduk, lakukan gerakan angkat dumbell yang dipegang dengan posisi telapak tangan kedepan secara bergantian".

Latihan beban akan meningkatkan kekuatan dan daya tahan otot, sekaligus membuat jasmani dan rohani kita menjadi lebih bugar. Perasaan bugar ini tidak dapat diperoleh dari jenis latihan apapun lainnya. Misalnya, bersepeda membantu membangun 1 jenis otot, bola basket membangun otot yang lain, namun latihan beban membuat otot kita bekerja secara menyeluruh dalam waktu yang singkat. Latihan beban secara rutin akan membantu membentuk kelompok otot tertentu, dan itu akan meningkatkan performa kita pada olahraga lainnya. Dan yang utama, latihan beban dapat meningkatkan otot tubuh kita. Dwi Anggoro(2011) Menurut Ade Rai (2008) mengatakan bahwa latihan beban terdapat berbagai latihan yang dapat dilakukan untuk membantu dalam rancangan program latihan sesuai dengan tujuan yang diinginkan. Berlatih dengan dumbell memiliki beberapa keunggulan dibandingkan dengan peralatan fitness lainnya yang digunakan dalam latihan beban. Misalnya, dengan sifat alaminya, latihan dumbell membuat Anda menstabilkan otot-otot yang penting untuk kekuatan, keseimbangan dan postur tubuh. Tidak seperti beberapa peralatan fitness yang menggunakan gerakan yang mungkin memerlukan Anda untuk membiasakan diri terlebih dahulu, latihan dumbell banyak menggunakan pergerakan pola alami tubuh dan juga menggabungkan berbagai gerakan yang lebih besar daripada peralatan fitness lain. Dan fleksibilitas dari latihan dumbell berarti bahwa Anda dapat menargetkan bagian tubuh tertentu dengan sangat efektif.

Oleh karena itu latihan dumbell sebenarnya tidak berhubungan langsung dengan cabang olahraga tinju disaat berlangsungnya pertandingan seperti mengangkat atau mendorong dumbell tersebut tetapi sangat dibutuhkan oleh petinju dalam proses latihan untuk membantu mengembangkan dan meningkatkan kemampuan fisik guna menunjang penampilan atlet dari segi teknik dan taktik kearah yang lebih sempurna.

Untuk itu peneliti mencoba untuk menerapkan latihan beban dumbell dalam upaya peningkatan kecepatan pukulan straight pada atlit tinju amatir tersebut. Dari bentuk latihan ini diharapkan dapat meningkatkan kecepatan pukulan pada atlit tinju amatir. 


\section{KECEPATAN PUKULAN STRAIGHT}

Pukulan straight adalah dasar dari keahlian bertinju, dan pukulan ini dalam sejarah pertinjuan perkembangannya paling akhir. Pukulan ini merupakan hasil pemikiran yang baik karena dapat dilaksanakan dengan lebih baik dan efektif bila dibandingkan dengan pukulan-pukulan lainnya.

Menurut Dianherlinawati (2010) mengatakan bahwa kekuatan adalah kemampuan otot untuk melakukan kontraksi guna membangkitkan ketegangan terhadap suatu tahanan. Kekuatan otot adalah komponen yang sangat penting guna meningkatkan kondisi fisik secara keseluruhan.

Pearce (2009) menjelaskan otot ialah jaringan yang mempunyai kemampuan khusus yaitu berkontraksi. Dan dengan jalan demikian maka gerakan terlaksana. Bila otot berkontraksi maka menjadi pendek, dan setiap serabut turut bergerak dengan berkontraksi, oleh karenanya setiap kontraksi otot hanya dirangsang oleh adanya syaraf.

Menurut Bashit Hery Purnomo (2008) kekuatan adalah kemampuan otot yang menghasilkan tegangan dan tenaga selama usaha maksimal baik secara dinamis maupun secara statis. Kekuatan otot ini akan meningkat bila seseorang melakukan latihan beban dengan dosis tertentu atau program latihan tertentu. Lebih lanjut dijelaskan tentang prinsip tersebut, sebagai berikut :

1. Kekuatan hanya meningkatkan secara berarti otot-otot yang aktif dan mendapat beban lebih dalam proses pelatihan. Oleh sebab itu program pelatihan yang menyeluruh harus menggunakan bermacam-macam pelatihan untuk menjamin bahwa seluruh otot penting dilatih.

2. Penelitian telah menunjukkan bahwa perolehan kekuatan adalah hanya terjadi pada kelompok kontraksi otot yang digunakan dalam pelatihan. Jadi misalnya pelatihan isometrik akan sangat efektif dalam menambah kekuatan isometrik dan akan kurang efektif dalam meningkatkan kekuatan yang lain seperti kekuatan isotonik dan isokinetik. Dengan demikian maka seorang atlit harus berlatih dengan pelatihan yang memiliki karakter kontraksi yang dibutuhkan dalam kegiatan olahraga yang dipilihnya.

Atlit yang terlatih dan memiliki koordinasi yang baik antara saraf dan otot, tampak gerakannya seolah-olah tidak bertenaga, rileks tapi memiliki refleks atau reaksi yang cepat dan pukulan yang keras sehingga gerakan dari setiap atlit kelihatan sempurna, mantap dan anggun.

Dalam bab ini akan dikemukakan kesimpulan penelitian sebagai tujuan akhir dari suatu penelitian yang dikemukakan berdasarkan hasil analisis data dan pembahasannya. Dari kesimpulan penelitian ini akan dikemukakan beberapa saran sebagai rekomendasi bagi penerapan dan pengembangan hasil penelitian.

\section{KESIMPULAN}

Berdasarkan hasil analisis data dan pembahasan maka hasil penelitian ini dapat disimpulkan sebagai berikut :

1. Ada pengaruh signifikan antara latihan push up terhadap kecepatan pukulan straight pada atlit tinju amatir Sasana Lipang Bajeng, Kabupaten Takalar.

2. Ada pengaruh signifikan latihan beban dumbell terhadap kecepatan pukulan straight pada atlit tinju amatir Sasana Lipang Bajeng Kabupaten Takalar.

3. Tidak ada perbedaan pengaruh signifikan antara latihan push up dengan latihan beban dumbell terhadap kecepatan pukulan straight pada atlit tinju amatir Sasana Lipang Bajeng Kabupaten Takalar. 


\section{DAFTAR PUSTAKA}

Arikunto, Suharsimi. 1996. Prosedur Penelitian Suatu Pendekatan Praktek. Penerbit PT. Rineka Cipta, Jakarta.

Bompa, T.O. 1984. Theory and Methodology of Training. Kendall, Hunt Publishing Company, Dubuque, IQWA.

Bompa.(2004), Kemampuan-kemampuan Biometrik dan Metode Pengembangannya. Padang: Departemen of Physical Education, York University Toroto, Ontario Canada.

Harsono. 1988. Coaching Dan Aspek-Aspek Psikologi Dalam Coaching. CV.

Tambak Kusuma, Jakarta.

Harsono. Prinsip-prinsip Pelatihan Fisik.Jakarta: KONI Pusat, 1993.

Husni, Agusta. 1996. Buku Pintar Olahraga. Penerbit CV. Mawar Gempita, Jakarta.

Insani.Sugiyono.(2005). Metode Penelitian Pendidikan. Jakarta.Iwan S. Metodelogi Kepelatihan. Bahan Untuk Penataran Pelatihan Olahraga. Jakarta, 1991.

I Putu Agustya Maswinatha. 2013 . perbandingan struktur tubuh dan komponen fisik petinju pelajar sasana lipang bajeng takalar dan sasana gowa raya. Skripsi.

Midgley, Rud. 2000. Ensiklopedi Olahraga. Penerbit Dahara Prize, Semarang. Narendra, Mayun. 2000. Seni Olahraga Tinju. Pengurus Besar Persatuan Tinju Amatir Indonesia (PB. PERTINA), Jakarta.

Nurhasan.(2001). Tes dan Pengukuran dalam Pendidikan Jasmani. Ritonga, Zulfan (2007). Statistika Untuk IImu-ilmu Sosial. Cendikia.

Sajoto, Mochamad. 1988. Pembinaan Kondisi Fisik Dalam Bidang Olahraga. Depdikbud Dirjen Dikti, Jakarta.

Sajoto.(1995). Peningkatan \& Pembinaan Kekuatan Kondisi Fisik Dalam Olahraga.Semarang. 95

Samaun, Kadir. 1995. Diktat Anatomi. Ujung Pandang.

Soeharno, H.P. 1985. IImu Kepelatihan Olahraga. Yayasan STO, Yokyakarta. Sudjana, Nana. 1986. Desain dan Analisis Eksperimen. Penerbit Tarsito,

Bandu

Suharno. (1992). Rencana Program Latihan. Jakarta, Direktorat Keolahragaan Ditjen Diklusepora Departemen Pendidikan dan Kebudayaan.

Suranto. 1994. Perbedaan Pengaruh Latihan Berbeban Dengan Irama Lambat Terhadap Daya Tahan Otot Lengan Serta Kecepatan Pukulan. Tesis IKOR UNAIR, Surabaya.

Syaifuddin. (1996). Anatomi Fisiologi Untuk Siswa Perawat. Jakarta, EGC 
Usman. H dan Akbar. S. (1998). Metodologi Penelitian Sosial. Bumi Aksara, Jakarta.

Zumerchik, John. (1997). Encyclopedia of Sport Science. Volume 2. New York, Macmillan Inc.

Jakarta. 2012. http: www. pp-pertina. com http:// galeripenjas.blogspot.com/2013/04/push-upvariasi http://www.sportobzor.ru/uploads/images Mar'at, 1991. diadaptasi dari teori Alport

Suprapto jiel, wongsolo Oktober 29, 2010. balian86

http: www.unja.ac.id/fe/images/karya-ilmiah/tabel-t.pdf 